\title{
Education, Employment and Economic Growth Nexus: A case study of Pakistan
}

\author{
Ambreen Sarwar ${ }^{1}$ \\ Atif Khan Jadoon ${ }^{2}$ \\ Aamir Azeem ${ }^{3}$
}

\begin{abstract}
Economic growth is a fundamental requirement for the development of a country. Therefore, the questions concerning the factors that can enhance the economic growth of a country are of immense importance especially for developing countries such as Pakistan. The present study provides evidence that promoting education and providing increased employment opportunities can produce positive return in the form of higher economic growth. It highlights the role that employment level and education can play in helping the economy to achieve rapid growth. To analyze the long-run and the short-run relationship among the key variables of interest, Johansen Co-integration test and Vector Error Correction Model (VECM) has been applied to annual time series data from 1980 to 2013. The empirical results confirm a positive long-run relationship between both employment and economic growth and education and economic growth.
\end{abstract}

Keywords: Pakistan, Education, Employment, Economic Growth, Co-integration

\section{INTRODUCTION}

Economic growth is a fundamental requirement for the development of a country. Economic growth of a country bears a strong relationship with the productivity of its labor force, entrepreneurial activities, employment opportunities, and the level of education in the country. In addition to these factors, the past literature related to economic growth suggests a range of other economic and non-economic factors (capital accumulation, technology, governance etc.) that may affect growth of the economy (Sala-i-Martin; 1997 and Bleaney \& Nishiyama; 2002).

The economic performance of countries varies with regard to the mentioned characteristics. Economic backwardness and laggard economic growth is interrelated with many factors, some of them being low labor efficiency and training, lack of business enterprising skills, less employment opportunities and slow growth in knowledge. On the other hand, countries that are more developed are rich in human capital. Therefore, one can say that education, employment and economic growth are dependent on one another. This connection is sometimes intriguing but can never be ignored, since the amalgamation of education and employment, organized and implemented appropriately, can strengthen the economic growth of a country.

Nations cannot develop without investing in education. Education involves a multidimensional process. It can contribute towards enhancing economic growth on one hand, and productivity on the other. Since the concept of human capital was introduced in the late 1950s, there is abundant research about the contribution of education to economic growth (Kiani \& Kausar, 2010, Kakar et al., 2011 and Hanushek \& Kimko, 2000). According to Gylfason and Zoega

1. Lecturer, Department of Economics University of Punjab, Lahore, Email: ambreen.sarwar@ hotmail.com

2. Lecturer ,Department of Economics University of Punjab, Lahore.

3. Lecturer, Department of Management Science, Virtual University of Pakistan, Lahore.

JISR-MSSE Volume 15

Jan-June2017 
(2003), education accelerates economic growth by enhancing human capital. Moreover, it also encourages economic growth by reducing inequality through improvement in physical capital and social capital of the society. Human capital has been recognized as an essential element for sustainable economic growth and hence development. The positive contribution of human capital through education development is well acknowledged. If educated people earn more than those without, the same must be true for nations as well.

Educated people get better jobs, earn more and are less likely to face unemployment than less educated people. Education may help to diminish corruption in a country, help create good governance, decrease inequality, reduce poverty and improve living standards of individuals. The multidimensional positive effects of education make it a vital component for policy framework (Kiani \& Kausar, 2010). Reduction in poverty and unemployment, and an improvement in economic and social infrastructure of the economy are important for sustainable economic growth in Pakistan. As mentioned, education is most important in improving economic and social infrastructure. Therefore, immense importance should be given to this sector.

According to United Nations Millennium Development Goals (MDGs), health and education are the primary pillars of development. This includes that attainment of universal primary education which has been marked as the second most important Millennium Development Goal. Given this fact and considering how important education is for the development of human capital, Pakistan should follow the example of other developed nations and focus its resources on establishing a strong education sector .

In addition to education, employment is another important factor detrimental to achieving economic growth, as seen by the examples of almost every country in the world (Seyfried, 2005 and Sodipe \& Ogunrinola, 2011). Access to employment opportunities will always be a crucial determinant of rapid economic growth, whether the majority of the working population is salaried workers or self-employed entrepreneurs, subsistence farmers or daily-wage earners. People, at large, derive almost all of their disposable income from working, regardless of profession. Hence the quality of jobs available in a country as well as the level of employment it achieves will, in turn, affect the level of economic growth attained. Provision of basic employment can prevent several types of social harms from existing in a society, such as suicide, street crime, and a generally high poverty rate. Achievement of a job represents achievement of revenue both at the individual and national level. Therefore, education and employment both play a vital role in accelerating economic growth for a nation. Since educational attainment, employment generation and enhancing economic growth are always a priority of governmental agenda around the world; questions concerning the potential relationship between the three are of immense importance. The present study examines the effect of education and employment on economic growth in Pakistan between the years 1980 and 2013. The organization of the rest of the paper is as follows; Section 2 presents literature review on the topic. Section 3 specifies the model and discusses the data, and section 4 describes the econometric methodology being followed in the analysis. In section 5, findings and results are discussed. Lastly, Section 6 contains a conclusive discussion about the issue at hand considering the results from section 5 .

4- MDGs were formulated in Sep, 2000 at UN Millennium Summit and consist of 8 goals that are to be achieved by 2015.

For further details, visit www.undp.org/mdg

16 Jan-June2017 $\quad$ Volume $15 \quad$ Number 12 JISR-MSSE 


\section{LITERATURE REVIEW}

Education and employment are universally recognized as primary tools to promote economic growth. Both undoubtedly play a very important role in economic growth by developing human capital, in terms of improved skills and productivity. Education and employment opportunities bring benefits for both individuals and the society as a whole. For developing countries such as Pakistan, education and employment play a crucial role in reducing poverty, and in eradicating both social and income inequalities. Considering the importance of education and employment, a plethora of studies examine the relationship between education, employment and economic growth. The review of the existing economic literature on the relationship between the three said variables was performed to find the research gap and solid justification for the present study.

Beginning with employment, it is one of the most important factors to achieve economic growth in approximately all countries of the world but there is a dearth of studies especially in case of developing countries that empirically analyze the relationship between the two. Seyfried (2005) examined the relationship between employment level and economic growth in USA. The analysis was based on ten largest states of the USA. Real Gross Domestic Product (GDP) and the out gap were both used to measure economic growth. Using quarterly dataset and fixed-effects estimation technique, the results of for the polled regressions showed that the employment elasticity of economic growth was 0.47 when using real GDP and it was 0.39 when considering output gap.

State specific model was estimated using Seemingly Unrelated Regression (SUR) technique. Results showed that a positive and significant relation exists between employment and economic growth. However, the magnitude of the elasticities (when considering real GDP) varied across the ten states with Jersey and Michigan having the largest elasticity of employment i.e. 0.61, and Texas having the lowest elasticity of 0.31 . On the other hand, when output gap was used instead, significant and positive relationships were found in nine of the ten states. In addition to this, by analyzing the lagged relationship, the study also concluded that economic growth not only has immediate impact on employment but its impact continues for several periods in majority of the states under consideration.

Similarly, Sodipe and Ogunrinola (2011) empirically analyzed the relationship between employment level and economic growth of Nigerian economy. Public expenditure and foreign direct investment were taken as regressors along with the GDP. GDP was also replaced by GDP growth rate in a separate model. The results indicated the existence of a strong positive correlation between employment and GDP. In contrast, a relatively weak correlation was found between the growth rate of GDP and the employment level in the economy. The regression results showed a positive and statistically significant employment elasticity of economic growth Nigeria. The study revealed that the Nigerian economy is not characterized by jobless growth and the high level of unemployment in Nigerian economy basically was due to relatively low employment intensity of GDP growth.

In addition, Chang Kon (2007) examined the effect of economic growth on employment for the Korean economy over the period 1971-2005. The equilibrium labor market models were used to analyze the effect of economic growth and other determinants on employment. The 
study highlighted that both demand side and supply side effects of growth are important and the employment elasticity of growth is determined both by structure of technology and preference i.e the labor demand and supply. Considering the results, the author concluded that slow employment growth in Korea was not only due to the labor saving technology. The above mentioned studies provide an insight into how economic growth effects employment, whereas the present study tries to uncover the relationship in the other direction i.e. analyzing the impact of employment opportunities on economic growth of Pakistan.

In addition to employment, education and economic growth are also intertwined. Education is very important for nations to develop. It has been endorsed by the neo-classical and Solow growth models that a positive relationship exists between education and economic growth because education helps to improve human capital. There are a number of studies that have investigated this relationship. Kiani and Kausar (2010) examined the role that education plays in promoting economic well-being. This was done by analyzing the economic growth of Pakistan for the period 1980-2007. Four different education levels (Primary school enrollment, Middle school enrollment, High school enrollment and other school enrollment) as a ratio to total employed labor force were considered for the purpose of analysis. Results showed that greater access to education definitely contributes to higher rates of economic growth.

There is a strong and positive relationship between the two. In this regard, the role of primary education is considered extremely important. The authors quote that these findings are consistent with the idea of Barro (1991), Becker et al. (1990), and Barro and Becker (1989).Since the role of education is very important in enhancing economic growth, the authors suggested that to ensure quality educational systems, information technology should be incorporated in teaching practices. This will enhance the effectiveness of the teaching practices and will provide greater job opportunities to the individuals in the future.

Kakar et al. (2011) investigated the relation between education expenditures and economic growth in Pakistan. Using Time series data for the period 1980-2009, Co-integration and error correction models were used to determine the long run and short run relation between of education and economic growth. The authors acknowledge that education undoubtedly plays an important role in economic growth by developing human capital, in terms of improved skills and productivity. Results of the study showed that though a significant relationship exists between education and economic growth in the long-run, the same is not true for the short-run. Therefore, improved standards of education positively affect the efficiency and productivity of the labor force and promote economic development in the long-run. The authors stated that quality of education plays a significant role in increasing efficiency of human capital and economic growth. Therefore, to encourage Research and Development $(R \& D)$ and improve the quality of education the share of public spending on education sector should be increased.

In this regard, Hanushek and Kimko (2000) discussed significant and positive impact of educational quality on productivity and economic growth rates. Moreover, Bils and Klenow, (2000), also pointed out, that countries with high enrolment rates in schools experience rapid improvement in productivity, and hence have faster growth in per capita income. 
Pradhan (2009) examined the causality between the educational expenditures of government and GDP in India from 1951-2001. Augmented Dickey Fuller (ADF) test was used to check the stationarity of the variables. The results of co-integration test showed that variables are co-integrated and there exists a long run relationship between government expenditure on education and economic growth. Authors also used Granger causality test to analyze the causal relationship between GDP and government expenditure on education. Test results showed that unidirectional causality exits from economic growth to educational expenditure by Government. These results are in the line with the results reported by Baldacci et al. (2004). Taking data on 120 developing countries from 1975-2000, authors found that a positive long-run relation exists between educational expenditures and economic growth.

Similarly, Danacica et al. (2010) also examined the causal relation between higher education and economic growth in Romania from 1980 to 2008. ADF test was used to check the stationarity of variables. Using bivariate VAR model and Granger causality test the results showed that there exists unidirectional causality between higher education and economic growth. As mentioned, there clearly exists a relationship between education, employment and economic growth. Education and employment both play a vital role in accelerating economic growth of a country. Apart from the direct relationship that exists between education and economic growth and employment and economic growth, this relationship can work through two indirect channels as well. Well educated individuals have better employment opportunities and better employment prospects help the economy to achieve rapid growth. However, this relationship does not always have to exist in the linear fashion stated. Employment and economic growth can also accelerate educational development which in turn can affect the former two variables. It can be employment that can bring improvement in education and then both can contribute toward economic growth. Better employment opportunities help the employees to earn a better living and focus more on education. Wheeler (1980) suggested that the level of income (through employment) might be influencing the level of education rather than the other way round.

Since employment and education are also interlinked, a variety of studies show relationship between education level and employment rate. People can increase their employment opportunity cost by investing in their education. Samiullah (2014) attempts to analyze the effect of health and education on employment rate in Pakistan from 1981-2012. Labor force participation rate was selected as the dependent variable and education (divided into total Public spending on education (\%age of GDP) and Literacy rate) and health (divided into total public spending on health (\%age of GDP) and life expectancy rate) were selected as the independent variables. The results showed that all the independent variables have significant effect on employment level. All the variables have positive impact on employment rate except life expectancy rate. The study suggests that people with higher level of education and greater health have more chances of being employed in the labor market because they are more productive, more skilled and more efficient. Similar analysis was also conducted by Faridi et al. (2010), whereby they highlight the importance of health and education for the human capital in Pakistan. Using Maximum Likelihood Logit Model, the paper reports that health and education both have a positive impact on employment.

The literature review above demonstrates that the relationship between education, employment and economic growth is a highly debated topic in literature related to growth and devel- 
opment, but there are rarely any studies on Pakistan that together find out the relationship between the three. Therefore, this paper intends to fill this gap by providing evidence from Pakistan. Based on the results, the study proposes the policy options that may become useful for the government in promoting economic growth and development.

\section{METHODOLOGY}

\section{Data Description and Model Specification}

The literature discussed in previous section shows the significance and the vital role of education and employment in promoting economic growth. Both education and employment are considered as the key determinants for promoting economic growth of an economy and there is a need to analyze the long run relationship between the three. For this purpose, the present study focuses on the economy of Pakistan and uses time series data from 1980-2013. In the model regressand is economic growth and regressors are education and employment. All variables are measured in millions.

For estimation, the following equation is used:

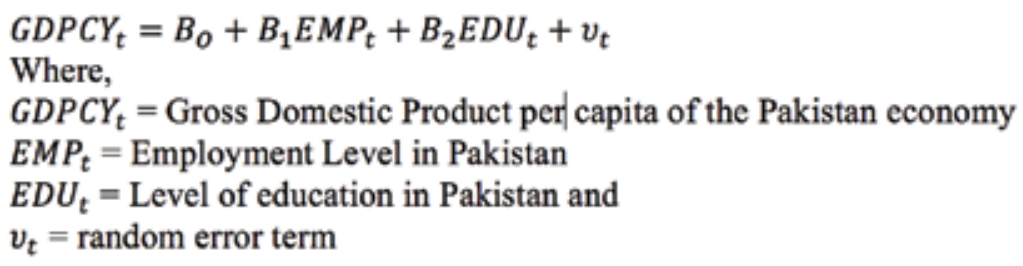

GDPCY shows per person income of the country. It is obtained by dividing GDP of the country by the total population. GDPCY is measured in millions and its data is collected from WDI (2013). EMP shows that number of people who are employed from the total labor force. In our study, EMP is measured by employed labor force in millions. EMP is measured in millions and data has been taken from International Labor Organization. Employed labor force has been used as a proxy of EMP as used by Seyfried (2005) and Faridi et al. (2010). EDU is measured using middle school enrollment (in thousands) as a proxy. EDU data has been taken from Economic survey of Pakistan.

\section{Unit Root Tests}

It is mandatory to check the stationarity of the variables used in the study. One of the common problem time series data possess is the non stationairty of the data which gives spurious results for the estimates. To test the stationarity of the data, present study uses Augmented Dickey-Fuller (ADF) test as presented Dickey and Fuller (1979).

\section{Co-integration Test}

When the variables of the interest are integrated of order one, Johansen and Juselius (1990) co-integration test is applied to confirm the long run relationship among the variables. Optimal lag length should be selected before applying Johansen and Juselius co-integration test so that error term is free of the problems of autocorrelation, heteroscedasticity and normality. Johansen and Juselius co-integration test methodology is based on Vector autoregression (VAR) model of order m given as: 


\section{Co-integration Test}

When the variables of the interest are integrated of order one, Johansen and Juselius (1990) co-integration test is applied to confirm the long run relationship among the variables. Optimal lag length should be selected before applying Johansen and Juselius co-integration test so that error term is free of the problems of autocorrelation, heteroscedasticity and normality. Johansen and Juselius co-integration test methodology is based on Vector autoregression (VAR) model of order m given as:

$\mathrm{Y}_{\mathrm{t}=} \alpha+A_{1} \mathrm{Y}_{t-1} \ldots \ldots \ldots+A_{m} \mathrm{Y}_{t-m}+\varepsilon_{t}$

Or alternatively,

$\mathrm{Y}_{\mathrm{t}=\alpha} \alpha+\sum_{k=1}^{m} \Pi_{k} \mathrm{Y}_{\mathrm{t}-\mathrm{k}}+\varepsilon_{\mathrm{t}}$

Where $\mathrm{Yt}$ is a vector of three variables and these variables should be integrated of order one, $\alpha$ is a vector of intercepts, $\Pi_{i}$ is a time-invariant $3 * 3$ matrix and $\varepsilon_{t}$ is a vector of white noise residuals having zero mean and constant variance.

The first difference form of the above model is written as:

$\Delta \mathrm{Y}_{\mathrm{t}=\alpha} \alpha+\sum_{k=1}^{m-1} \Gamma_{k} \Delta \mathrm{Y}_{\mathrm{t}-\mathrm{k}}+\Pi \mathrm{Y}_{\mathrm{t}-1}+\varepsilon_{t}$

Where

$\Pi=\sum_{i=1}^{m} \mathrm{~A}_{i}-\mathrm{I}$ and $\Gamma_{i}=-\sum_{j=i+1}^{m} \mathrm{~A}_{j}$

Where $\mathrm{Y}_{\mathrm{t}}$ and $\varepsilon_{t}$ are defined as earlier and $\mathrm{k}$ is the lag length. Here $\Pi$ is impact matrix of $3 * 3$ as three variables were considered in the present study. $\Pi$ Indicate the long run relationship among variables. The rank $\left(\Gamma_{i}\right)$ of $\Pi$ gives information about the total co-integrating relationships in the model.

Johansen (1995) established two test, trace test and maximum eigenvalue test, to determine the number of co-integrating vector in a model. If the two tests give different results then it is advisable to rely on $\lambda_{\text {trace }}$ test because trace test has more power and is superior to $\lambda_{\max }$ test. Trace test is particular advantageous if there are at least two more co-integrating relations than specified under the null hypothesis (Lutkepohl et al., 2001).

\section{Trace Statistics}

$$
\lambda \operatorname{trace}(\mathrm{r})=-\mathrm{N} \sum_{l=r+1}^{j} \ln \left(1-\lambda_{l}\right)
$$

The null hypothesis $\left(\mathrm{H}_{0}\right)$ of this test states that the number of co-integrating relationship is less than equal to " $r$ " while the alternative hypothesis $\left(\mathrm{H}_{1}\right)$ states that the number of co-integrating relationships is greater than " $\mathrm{r}$ ". Here $\mathrm{N}$ is total number of observations, $\mathrm{j}$ shown total number of variables and $\lambda$ is the eigen value (s). 
Maximal Eigen Value Test Statistics

$$
\lambda_{\max }(\mathrm{r}, \mathrm{r}+1)=-\mathrm{N} \ln \left(1-\lambda_{\mathrm{r}+1}\right)
$$

The null hypothesis (H0) of this test states that there are at most " $r$ "co-integrating vectors while alternative hypothesis $(\mathrm{H} 1)$ states that co-integrating vectors must be equal to $\mathrm{r}+1$.

\section{Vector Error Correction Model (VECM)}

If there exists co-movement among the variables of interest then while checking the stable long-run relation, we may estimate VECM. VECM is used to examine both short-run and long-run equilibrium. Pre-requisite for applying the VECM is that variables used in a model must be stationary at level one and at least one co-integrating relation must be present among the chosen variables for the study. VECM of the present study is given as under:

$$
\begin{aligned}
& \triangle G D P C Y_{1 t}=\alpha_{10}+\sum_{i=1}^{p} \alpha_{11, i} \Delta G D P C Y_{1, t-i}+\sum_{i=1}^{p} \alpha_{12, i} \Delta E M P_{2, t-i}+\sum_{i=1}^{p} \alpha_{13, i} \Delta E D U_{3, t-i}
\end{aligned}
$$

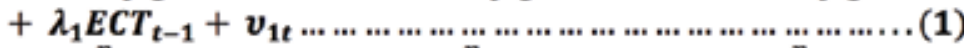

$$
\begin{aligned}
& \Delta E M P_{2 t}=\alpha_{20}+\sum_{i=1}^{p} \alpha_{21, i} \Delta G D P C Y_{1, t-i}+\sum_{i=1}^{p} \alpha_{22, i} \Delta E M P_{2, t-i}+\sum_{i=1}^{p} \alpha_{23, i} \Delta E D U_{3, t-i}
\end{aligned}
$$

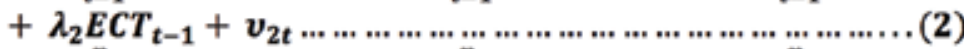

$$
\begin{aligned}
& \Delta E D U_{3 t}=\alpha_{30}+\sum_{i=1}^{p} \alpha_{31, i} \Delta G D P C Y_{1, t-i}+\sum_{i=1}^{p} \alpha_{32, i} \Delta E M P_{2, t-i}+\sum_{i=1}^{p} \alpha_{33, i} \Delta E D U_{3, t-i} \\
& +\lambda_{3} E C T_{t-1}+v_{3 t}
\end{aligned}
$$

Where

$\Delta$ is the first difference operator, $\mathrm{p}$ shows lag length and $\mathrm{ECT}_{\mathrm{t}-1}$ shows error term in lagged form. ECT indicates long-run convergence and its coefficient shows the extent by which long-run equilibrium of dependent variable is attained in every period. The long-run stability of the equilibrium path can be confirmed if the coefficient of $\mathrm{ECT}_{\mathrm{t}-1}$ is negative and significant.

\section{Diagnostic Tests}

Diagnostic tests have been applied to check the robustness of the results. For the present study VECM based Langragian Multiplier (LM) test for serial correlation in error terms, White Test for heteroscedasticity and Jarque- Bera test for normality have been used.

\section{Stability Test}

The stability of the coefficients of both short-run and long-run have been checked through CUSUM and CUSUMSQ test of recursive residuals as discussed by Brown et al. (1975). 


\section{EMPIRICAL RESULTS AND DISCUSSION}

\section{Unit Root Test Results}

Results for the ADF test for level and for the first difference are summarized in Table 1 and 2.

Table 1: Results of ADF at level

\begin{tabular}{ccc} 
Variables & \multicolumn{2}{c}{ ADF values at level } \\
& Intercept & Intercept and Trend \\
\hline GDPCY & -0.439329 & -2.262721 \\
\hline EMP & 2.026966 & -1.039293 \\
\hline EDU & 0.019651 & -2.193302 \\
& Critical Values & \\
\hline $1 \%$ & -3.679322 & -4.309824 \\
\hline $5 \%$ & -2.967767 & -3.574244 \\
\hline $10 \%$ & -2.622989 & -3.221728
\end{tabular}

$*$ shows significance of the variable at $1 \%$ and $* *$ shows significance at $5 \%$ and $* * *$ shows significance at $10 \%$.

Table 2: Results of ADF at first difference

\begin{tabular}{ccc} 
Variables & \multicolumn{2}{c}{ ADF values at first difference } \\
& Intercept & Intercept and Trend \\
\hline GDPCY & $-3.178015^{*}$ & -3.115803 \\
\hline EMP & $-5.476224^{*}$ & $-6.467452^{*}$ \\
\hline EDU & $-4.474027^{*}$ & $-4.394698^{*}$ \\
& & \\
& Critical Values \\
\hline $1 \%$ & -3.670170 & -4.296729 \\
\hline $5 \%$ & -2.963972 & -3.568379 \\
\hline $10 \%$ & -2.621007 & -3.218382
\end{tabular}

$*$ shows significance of the variable at $1 \%$ and $* *$ shows significance at $5 \%$ and $* * *$ shows significance at $10 \%$.

Results indicate that all the variables are non-stationary at level. All the variables become stationary when the series are first-differenced. This shows that the variables taken for the study are integrated of order one.

\section{Selection of Maximum Lag Length}

The next step in estimation process is to check the maximum lag legth. Results for the determination of lag length using different criteria are presented in table 3.

\begin{tabular}{llll}
\hline JISR-MSSE & Volume 15 & Number 1 & July-Dec 2016 \\
$\mathbf{2 3}$
\end{tabular}


Table 3: Results of the lag selection criteria

\begin{tabular}{ccccc} 
Lag & $\begin{array}{c}\text { Final prediction } \\
\text { error (FPE) }\end{array}$ & $\begin{array}{c}\text { Akaike information } \\
\text { criterion (AIC) }\end{array}$ & $\begin{array}{c}\text { Schwarz information } \\
\text { criterion (SC) }\end{array}$ & $\begin{array}{c}\text { Hannan-Quinn } \\
\text { information criterion (HQ) }\end{array}$ \\
\hline 0 & $3.01 \mathrm{e}+15$ & 44.15442 & 44.29715 & 44.19805 \\
\hline 1 & $7.09 \mathrm{e}+12$ & 38.09679 & $38.66774 *$ & 38.27134 \\
\hline 2 & $6.08 \mathrm{e}+12 *$ & $37.91704^{*}$ & 38.91619 & $38.22249^{*}$
\end{tabular}

*Indicates lag order selected by the criterion

The next step in estimation process is to check the maximum lag legth. Results for the determination of lag length using different criteria are presented in table 3.

\section{Selection of Maximum Lag Length}

Results of ADF test revealed that all the variables used in the study are integrated of level one. Since there is a possibilty of the existenace of long-run relationship among variables, Johansen Co-integration test is applied to check this relationship. The results of the trace test and the maximum eigenvalue test are reported in table 4 and 5 respectively.

Table 4: Trace test results

H0 H1 Trace Statistics $\quad$ Critical Value

\begin{tabular}{lllcc}
\hline $\mathrm{r} \leq 0^{*}$ & $\mathrm{r}>1$ & 38.72668 & 35.19275 & $0.0199^{*}$ \\
\hline $\mathrm{r} \leq 1^{*}$ & $\mathrm{r}>2$ & 20.34794 & 20.26184 & $0.0487^{* *}$ \\
\hline $\mathrm{r} \leq 2$ & $\mathrm{r}>3$ & 6.215384 & 9.164546 & 0.1747
\end{tabular}

*Represents that the null hypothesis is rejected at $5 \%$ level.

Trace test indicates that we have two co-integrating vectors. This confirms the long-run relation among the variables. The maximum Eigen statistics is reported in table 5.

Table 5: Maximum Eigen value test results

\begin{tabular}{ccccc} 
H0 & H1 & Max-Eigen Statistics & $\begin{array}{c}\text { Critical Value } \\
\text { At 5\% level }\end{array}$ & \\
\hline $\mathrm{r}=0$ & $\mathrm{r}=1$ & 18.37874 & 22.29962 & 0.1615 \\
\hline $\mathrm{r}=1$ & $\mathrm{r}=2$ & 14.13256 & 15.89210 & 0.0926 \\
\hline $\mathrm{r}=2$ & $\mathrm{r}=3$ & 6.215384 & 9.164546 & 0.1747
\end{tabular}

*Represents that the null hypothesis is rejected at $5 \%$ level.

The results of maximum eigenvalue test do not confirm existence of relationship among variables. Since trace and maximum eigenvalue tests give different results, we rely on the trace test (Lutkepohl et al., 2001).

The results confirm that economic growth, employment and education are moving in the same direction in the long-run. Furthermore, since the concern of the study is to analyze the reaction of economic growth to employment and education, the co-integrating vectors are normalized by economic growth. The results of normalized equation are given in Table 6 .

24 Jan-June2017 $\quad$ Volume $15 \quad$ Number 12 JISR-MSSE 
Table 6: Normalized equation of co-integration

Dependent Variable $=$ GDPCY

\begin{tabular}{cccc}
\hline Variables & Coefficient & S.E & t-values \\
\hline Constant & -244.2253 & 18.4358 & -13.24734 \\
\hline EMP & 7.542496 & 1.20267 & 6.271459 \\
\hline EDU & 0.018955 & 0.00784 & 2.41773
\end{tabular}

These results, represented in equation form are given as:

$$
\begin{aligned}
& G D P C Y_{t}=-244.2253+7.542496 E M P_{t}+0.018955 E D U_{t} \\
& \begin{array}{lll}
\text { t-values } & (-5.672375) & (6.271459)
\end{array}
\end{aligned}
$$

The results indicate that all variables used in this model significantly relate with the economic growth of Pakistan. Significant and positive long-run relationship between economic growth and education is confirmed by the results of the study and these results are in line with the findings of Kiani and Kausar (2010). The positive relation between economic growth and education indicates that for Pakistan, human capital development is one of the most significant factors for achieving stable long-run growth and development. Human capital through educational development can play a vital role in the life of masses to help them overcome the complexities of economic growth in Pakistan. Since educated people earn more than those without education, same is true for countries or economies as well.

Moreover, results verify significant and positive relationship between economic growth and employment for Pakistan. Increased and better employment opportunities increase labor productivity which in turn stimulates the revenue generation process. This positively enhances personal and household incomes in particular and income of the economy as a whole. Economy also experiences increased growth through multiplier effects of employment opportunities on the local economy. Moreover, better employment opportunities also enhance financial viability and social stability of the economy and hence accelerate economic growth.

\section{Vector Error Correction Model (VECM) results}

Since results of ADF and co-integration tests show that the variables are stationary at first difference and are integrated of order one, VECM with two cointegrating relations can be estimated. VECM results are presented in Table 7. Section "A" of the table shows dynamics of short-run and long-run for the three equations and in section B summary statistics are reported. 
Table 7: VECM Results

\begin{tabular}{|c|c|c|c|}
\hline \multicolumn{4}{|c|}{ Section A } \\
\hline Variables & $\begin{array}{l}\text { Equation.1 } \\
\text { D(GDPCY) }\end{array}$ & $\begin{array}{c}\text { Equation.2 } \\
\text { D(EMP) }\end{array}$ & $\begin{array}{c}\text { Equsation.3 } \\
\text { D(EDU) }\end{array}$ \\
\hline Constant & $\begin{array}{c}4.920850 \\
(1.394931)\end{array}$ & $\begin{array}{l}1.177313^{*} \\
(3.004715)\end{array}$ & $\begin{array}{c}93.56604 \\
(0.827514) \\
\end{array}$ \\
\hline $\mathrm{D}\left(\mathrm{GDPCY}_{\mathrm{t}-1}\right)$ & $\begin{array}{l}0.395779^{*} \\
(2.441448)\end{array}$ & $\begin{array}{c}0.024383 \\
(1.354197) \\
\end{array}$ & $\begin{array}{c}1.177622 \\
(0.226644)\end{array}$ \\
\hline $\mathrm{D}\left(\mathrm{GDPCY}_{\mathrm{t}-2}\right)$ & $\begin{array}{c}0.341190 \\
(1.725221)\end{array}$ & $\begin{array}{l}0.046086^{*} \\
(2.098065)\end{array}$ & $\begin{array}{c}3.274085 \\
(0.516514)\end{array}$ \\
\hline $\mathrm{D}\left(\mathrm{EMP}_{\mathrm{t}-1}\right)$ & $\begin{array}{l}-4.382118^{*} \\
(-2.322165)\end{array}$ & $\begin{array}{c}-0.356166 \\
(-1.699264)\end{array}$ & $\begin{array}{c}19.51198 \\
(0.322593)\end{array}$ \\
\hline$D\left(E^{\prime} P_{t-2}\right)$ & $\begin{array}{c}-1.733252 \\
(-0.947119)\end{array}$ & $\begin{array}{c}-0.136946 \\
(-0.673752)\end{array}$ & $\begin{array}{c}-13.49436 \\
(-0.230059)\end{array}$ \\
\hline $\mathrm{D}\left(\mathrm{EDU}_{\mathrm{t}-1}\right)$ & $\begin{array}{c}0.009222 \\
(1.178292)\end{array}$ & $\begin{array}{c}-0.000523 \\
(-0.602197)\end{array}$ & $\begin{array}{c}0.149819 \\
(0.597245)\end{array}$ \\
\hline $\mathrm{D}\left(\mathrm{EDU}_{\mathrm{t} \cdot 2}\right)$ & $\begin{array}{l}0.021773^{*} \\
(2.717031)\end{array}$ & $\begin{array}{c}-0.002068 \\
(-2.323858)\end{array}$ & $\begin{array}{c}-0.116984 \\
(-0.455461)\end{array}$ \\
\hline $\mathrm{ECT}_{\mathrm{t}-1}$ & $\begin{array}{l}-0.541813^{*} \\
(-3.548570)\end{array}$ & $\begin{array}{c}-0.011845 \\
(-0.698451)\end{array}$ & $\begin{array}{c}0.391611 \\
(0.080021)\end{array}$ \\
\hline \multicolumn{4}{|c|}{ Section B } \\
\hline R-Square & 0.699280 & 0.540584 & 0.112874 \\
\hline Adjusted. R- Square & 0.565627 & 0.336399 & -0.281405 \\
\hline F-statistic & 5.232053 & 2.647520 & 0.286279 \\
\hline
\end{tabular}

* shows significance of the variable and t values are presented in parenthesis.

Results of equation 1 show that lagged GDPCY, lagged EMP and Lagged EDU have a significant short-run relationship with economic growth. The coefficient of ECT of economic growth variable is -0.541813 . The ECT term is negative and is significant as well. Therefore, economic growth is adjusted by almost $54 \%$ from short-run to its long-run equlibirum level. The significant and negative coefficient of ECT confirms the stability of this model and depicts a high speed of convergence towards the long-run equilibrium. The coefficient of ECTof EMP is also negative but is insignificant. While the coefficient of ECTof EDU does not carry the correct sign and is insignificant as well. However, we are only concrned with the results of equation 1 because GDPCY is our dependent variable of interest.

\section{Diagnostic tests results}

The results of the diagnostic tests are summarized in Table 8.

Table 8: Diagnostic tests Results

\begin{tabular}{ccc} 
Test Statistics & Prob. & Conclusion \\
\hline LM Test $(0.408660)$ & 0.5383 & No auto correlation \\
\hline Jarque- Bera $(2.484226)$ & 0.288773 & $\begin{array}{c}\text { Error terms are } \\
\text { normally distributed }\end{array}$ \\
\hline $\begin{array}{c}\text { Breusch Pagan } \\
\text { Godfrey }(0.492619)\end{array}$ & 0.7735 & No Hetroskesdasicity
\end{tabular}

Results suggest the absence of heteroskedasticity and serial correlation. Moreover, the residuals are also normally distributed. So all the tests show satisfactory results and confirm the validity of the estimates. 


\section{CUSUM and CUSUMSQ Test of Stability}

The results of both tests endorse the stability of the model if the central line representing the test remains within 5\% critical bounds. The graphs of the CUSUM and CUSUMSQ tests are presented in figure 1 and 2.
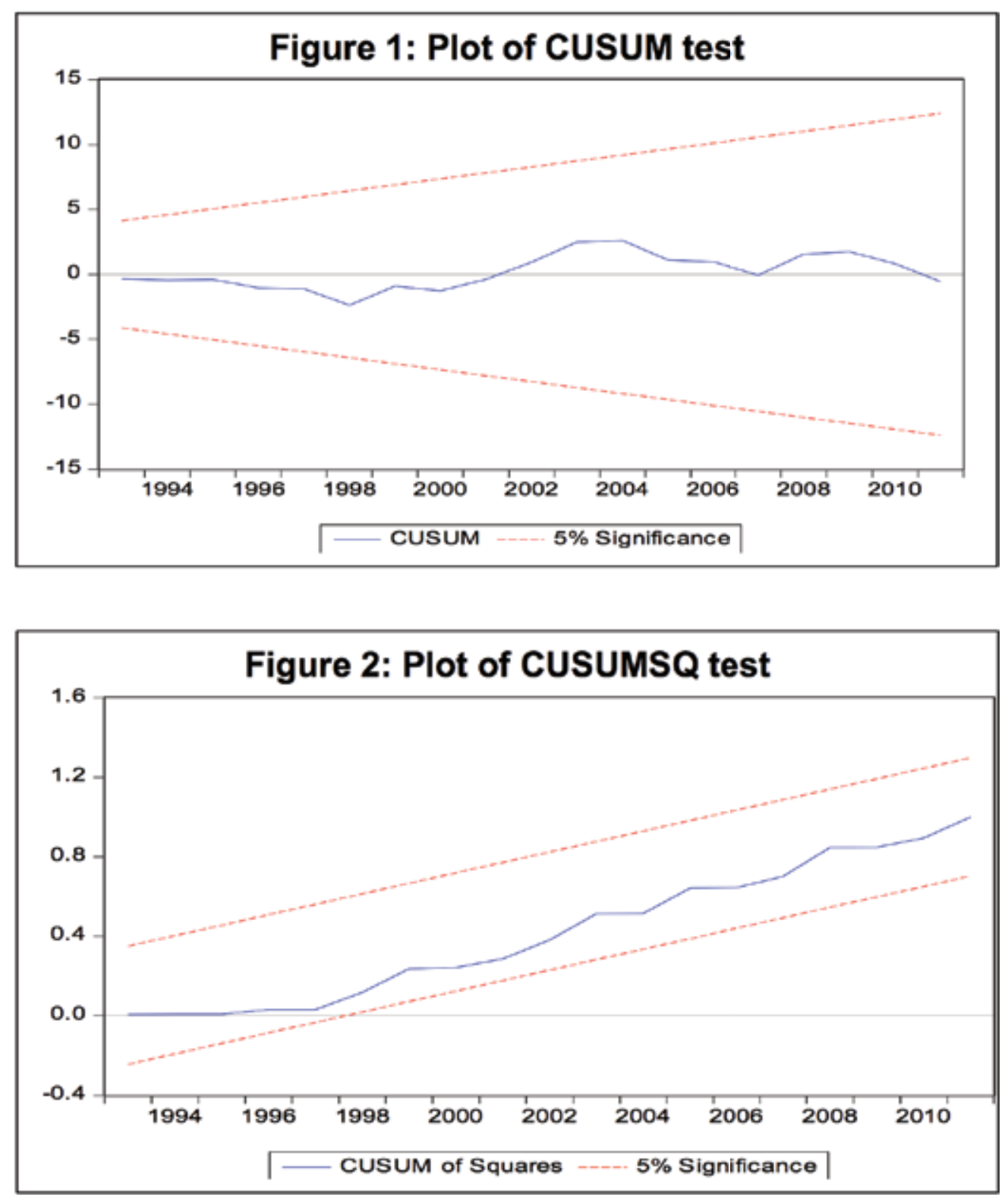

The graphs of the CUSUM and CUSUMSQ tests show that both the plots remain within the critical bounds. This confirms the structural stability of the model. 


\section{CONCLUSION AND POLICY RECOMMENDATIONS}

Achieving rapid economic growth is always a priority of governmental agenda around the world. Economic growth may bring with it many positive social changes that become very important, especially for the development of developing countries that have lower level of social welfare and weak institutions. Thus, the questions concerning the factors that can enhance the economic growth of any country are of immense importance, but especially of importance with reference to developing countries. The study suggests the widely held belief that investing in education and providing better employment opportunities promotes economic growth is correct overall. Key findings of the study suggest a significant and positive long-run relationship of both employment and education with economic growth. The review provides evidence that promoting education and providing increased employment opportunities can produce positive return in the form of higher growth rate of the economy.

It can be concluded on the basis of the results that policy makers must concentrate on increasing the level of education and employment to accelerate growth. Improved education standards not only increase the efficiency but also increase the productivity of the labor force which can contribute towards achieving long-run development goals of the country. The government, with competent administration, must raise the share of education sector in the budget and increase the quality of education along with focusing on the research and development. Moreover, the government should continue its market-based reforms in education, for example streamlining the requirements and processes to establish new free schools such as Danish School Project. Here, focusing on the quality of education is immensely important because the effect of education on economic growth can be pronounced with the high quality of education. Furthermore, considering specifically the case of Pakistan, where female education and labor force participation is an important issue, the government should promote education and skills development, especially among women, by expanding the policy focus and spending on providing education and skills development to their populations.

In addition to focusing on education, the goal of the government should also be to radically expand employment opportunities as widely as possible. Both increased education and improved employment opportunities increase the growth rate of the economy. Our recommendations identify that to achieve rapid economic growth, an organized effort towards consolidating high level of education and improved employment conditions in Pakistan should be made by the government. Hence, our study calls upon the need for targeted efforts on the part of the government of Pakistan to make conceited efforts towards raising awareness and literacy as well as providing employment opportunities to enable all individuals to take part in economic progress of the country. 


\section{REFERENCES}

Baldacci, E., Clements, B., Gupta, S., \& Cui, Q. 2008, 'Social Spending, Human Capital, and Growth in Developing Countries', World Development, 36 (8), 1317- 1341.

Bils, M. \& Klenow. 2000, 'Does Schooling Cause Growth?', American Economic Review, 90, 1160-1183.

Bleaney, M. \& Nishiyama, A. 2002, 'Exploring Growth: A Contest between Models', Journal of Economic Growth, 7, 43-53.

Brown, R. L., Durbin, J. \& Evans, J. M. 1975, 'Techniques for Testing the Constancy of Regression Relationship over Time', Journal of Royal Statistical Society, 37 (2), 149-163.

Brown, R. L., Durbin, J. \& Evans, J. M. 1975, 'Techniques for Testing the Constancy of Regression Relationship over Time', Journal of Royal Statistical Society, Series B, $37,149-192$.

Chang Kon, C. 2007, 'The Employment Effect of Economic Growth: Identifying Determinants of Employment Elasticity', Chonbuk National University.

Danacica, D-E Belascu, L. and Llie, L. 2010, 'The Interactive Causality between Higher Education and Economic Growth in Romania', International Review of Business Research Papers, 6 (4), 491 - 500.

Dickey, D.A. \& Fuller, W.A. 1979, 'Distribution of the Estimators for Autoregressive Time Series with a Unit Root', Journal of the American Statistical Association, $74,427-431$.

Faridi,M.Z., Malik, S., \& Ahmad, R.I. 2010, 'Impact of Education and Health on Employment in Pakistan: A Case Study', European Journal of Economics, Finance and Administrative Sciences, 18, 58-68.

Gylfason, T. \& Zoega,G. 2003, 'Education, Social Equality and Economic Growth: A View of the Landscape', CESifo Economic Studies, 49 (4), 557-579.

Hanushek, E.A. \& Kimko, D.D. 2000, 'Schooling, Labor Force Quality, and the Growth of Nations', American Economic Review, 90 (5), 1184-1208.

Johansen, S. \& Juselius, K. 1990, 'Maximum Likelihood Estimation and Inference on Co-integration - with Applications to the Demand for Money' Oxford Bulletin of Economics and Statistics, 52(2), 169-210.

Johansen, S. 1995, 'Likelihood Based Inference in Co-integrated Vector Autoregressive Models', Oxford University Press, Oxford. 
Kakar, Z.K., Khilji, B.A. \& Khan, M.J. 2011, 'Relationship between Education and Economic Growth in Pakistan: A Time Series Analysis', Journal of International Academic Research, 11(1), 27-32.

Kiani \& Kausar, A. 2010, 'The Role of Education on Economic Growth in Pakistan', Federal Urdu University of Arts, Science and Technology, Islamabad, Pakistan.

Liew, V.K.S. 2004, 'Which Lag Length Selection Should We Employ?', Economics Bulletin, 3 (33), 1-9.

Lutkepohl, H., Saikkonen, P. \& Trenkler, C. 2001, 'Maximum Eigenvalue versus Trace Tests for the Co-integrating Rank of A VAR Process', Econometrics Journal, 4, 287-310.

Pradhan, R.P. 2009, 'Education and Economic Growth in India: Using Error Correction Modelling', International Research Journal of Finance and Economics, 25,139-147.

Sala-i-Martin, X. 1997, 'I Just Ran Two Million Regressions', American Economic Review, 87, 178-183.

Samiullah. 2014, 'Relationship between Education, Health and Employment. A Time Series Analysis of Pakistan', Journal of Economics and Sustainable Development, $5(7), 50-54$.

Seyfried, W. 2005, 'Examining the Relationship between Employment and Economic Growth in the Ten Largest States' Southwestern Economic Review, 13-24.

Sodipe, Q.A., \& Ogunrinola. Q.I. 2011, 'Employment and Economic Growth Nexus in Nigeria' International Journal of Business and Social Science, 11(2), 232-239. 